\title{
Bio-Efficacy and Phyto-Toxicty of Azoxystrobin 23\% SC against Powdery Mildew (Oidium mangiferae) and Anthracnose (Colletotrichum gloeosporioides) Diseases in Mango
}

\author{
M.R. Ravikumar ${ }^{1 *}$, Vithal Navi², Yashaswini Sharma ${ }^{3}$ and Tippesh Chavhan ${ }^{4}$ \\ ${ }^{1}$ Department of Plant Pathology, ${ }^{2}$ Department of Agricultural Microbiology, ${ }^{3}$ Department of \\ Horticulture, College of Agriculture, Hanumanamatti, Haveri, Karnataka-581115, India \\ ${ }^{4}$ Institute of Organic Farming, University of Agricultural Sciences, Dharwad, Karnataka, India \\ *Corresponding author
}

\author{
A B S T R A C T
}

\begin{tabular}{l} 
K e y w o r d s \\
Mango, \\
Powdery mildew, \\
anthracnose, \\
Azoxystrobin, \\
Phyto-toxicity. \\
\hline Article Info \\
$\begin{array}{l}\text { Accepted: } \\
\text { 04 September } 2017 \\
\text { Available Online: } \\
\text { 10 October } 2017\end{array}$ \\
\hline
\end{tabular}

Mango (Mangifera indica L.) is one of the best fruit in the world market affected by two fungal diseases, powdery mildew and anthracnose causing up to 90 per cent crop loss. Hence, an investigation was initiated to study the bio-efficacy of different standard and new fungicides against powdery mildew and anthracnose disease. The experiment was conducted at humid tropical regions of Karnataka, India during 2012-14 with six treatments of different fungicides, viz., Azoxystrobin 23\% SC @ 1ml/L of water, Azoxystrobin 23\% SC @ 2ml/L of water, Standard Azoxystrobin 250 SC (market Sample) @ 1 $\mathrm{ml} / \mathrm{L}$ of water, Standard Hexaconazole 5\% SC @ 2ml/L of water, Standard Copper oxy chloride $50 \%$ WG @ 2.4g/ L of water along with one untreated Control. Two sprays were taken up at 20 days interval during flowering stage. Among the different treatments, Azoxystrobin 23\% SC @ 2ml/L of water recorded significantly lower per cent disease index of powdery mildew on leaves, inflorescence and fruits (17.75, 17.24 and 16.64, respectively) than control (53.53, 51.94 and 50.10 per cent disease index on leaves, inflorescence and fruits, respectively). The same treatment recorded minimum incidence of anthracnose (6.94) and maximum productivity (28.63 t/ha) as compared to control (14.85 and $12.85 \mathrm{t} /$ ha, respectively). There were no visual symptoms of phyto-toxicty noticed in terms of leaf tips and surface injury, wilting, necrosis, epinasty and hyponasty on mango crop by Azoxystrobin 23\% SC treatment even at 4ml/L concentration.

\section{Introduction}

Mango (Mangifera indica L.) is one of the most popular juicy stone fruit belonging to the family Anacardiaceae. It is cultivated in frostfree tropical and warmer subtropical climates recognized as king of fruits. It is one of the best fruit in the world market because of its excellent flavor, attractive fragrance, beautiful colour, delicious taste and nutritious value. India stands first in global mango production $(52 \%)$. However, the productivity of mango is affected by various diseases. Two fungal diseases, powdery mildew and anthracnose, are the primary causes of poor fruit set and yield in mango. Worldwide, mango powdery mildew is a sporadic, infects panicles, fruits and leaves causing up to 90 per cent crop loss (Nelson, 2008a). The fungus Oidium mangiferae Berthet, causing powdery mildew of mango, is widely distributed throughout the tropics. 
The ubiquitous fungus Colletotrichum gloeosporioides Penz and Sacc. is the anamorph stage occur on leaves, twigs, petioles, panicles and fruits. Ripe fruits affected by anthracnose develop sunken, prominent, dark brown to black decay spots before or after picking (Ploetz, 1999). Wet, humid, warm weather conditions favor powdery mildew and anthracnose infections in the field. Warm, humid temperatures favor postharvest anthracnose development (Nelson, 2008b).

Chemical control has been the most effective method adopted by farmers to protect their crops from fungal pathogens. The pathogens have started developing resistance against the conventionally used fungicides recommended to the farmers. Second generation fungicides have proved as a new ray of hope in better management of diseases under field conditions. Azoxystrobin is one an efficient fungicide which could control both powdery mildew and anthracnose disease together. The fungicide azoxystrobin belongs to the strobilurins, a recently introduced group of agrochemical fungicides (Margot et al., 1998). Hence, an investigation was initiated to study the bio-efficacy of Azoxystrobin 23\% SC along with different standard fungicides against powdery mildew and anthracnose disease.

\section{Materials and Methods}

The experiment was conducted at humid tropical regions of Karnataka, India during 2012-14 with six treatments of different fungicides, viz., Azoxystrobin 23\% SC @ $1 \mathrm{ml} / \mathrm{L}$ of water, Azoxystrobin 23\% SC @ $2 \mathrm{ml} / \mathrm{L}$ of water, Standard Azoxystrobin $25 \mathrm{SC}$ (market sample) @1 $1 \mathrm{ml} / \mathrm{L}$ of water, Standard Hexaconazole 5\% SC @ 2ml/L of water, Standard Copper oxy chloride 50\% WG @ $2.4 \mathrm{~g} / \mathrm{L}$ of water along with one untreated Control. 10 years old Alphonso mango plantations of 1000 square meter area was selected for each treatment. Two sprays were taken up at 20 days interval during flowering stage (in the month of January). The experiment was laid out in Randomized Block Design (RBD) with four replications. The observations on powdery mildew disease were recorded before and after each spray. Observations on anthracnose disease were recorded seven days after the first spray and the productivity of the plantation was also recorded. Ten plants were examined randomly and scored for disease severity by following $0-5$ scale. The details of scales are as shown below.

0 - No disease symptoms.

1 - Up to 10 per cent leaf / stem / inflorescence/ fruit area infected

2 - 11-25 per cent leaf / stem / fruit area infected

3 - 26-50 per cent leaf / stem / fruit area infected

4 - More than 50 per cent leaf / stem / fruit area infected

\section{5 - Complete drying of leaf / stem / fruit}

Further, the scale was converted into severity (Per cent Disease Index i.e. PDI) using the formula given by Wheeler (1969).

PDI $=$ (Sum of numerical rating $/$ Total number of leaves examined $) \times(100 /$ Maximum grade value)

Phyto-toxicty of fungicides in Mango: Phytotoxicty observation on 0-10 scale for leaf tips and surface injury, wilting, necrosis, epinasty and hyponasty. Three plants were selected at random from each treatment and the total number of leaves and those showing phyto- 
toxicty were counted. The data collected were converted in to percentage. The extent of phyto-toxicty is recorded based on scores given in Table 1.

\section{Results and Discussion}

\section{Efficacy of Azoxystrobin on powdery mildew}

The two years pooled data of 2012-13 and 2013-14 on per cent disease index (PDI) on leaves, inflorescence and fruits as influenced by different fungicides against powdery mildew is presented in Tables $2,3 \& 4$ respectively. The result presented in Table 2 revealed that, all the fungicidal treatments were found effective in reducing the disease index of Powdery Mildew in mango over control. Among the different treatments, Azoxystrobin 23\% SC @ 2ml /L recorded significantly low PDI (19.28) on leaves resulted 66.84 per cent reduction in PDI over control (Table 2). Anand et al., (2008) got similar results while studying the bio-efficacy of azoxystrobin (Amistar 25 SC) against cucumber downy mildew and powdery mildew diseases and were successfully arrested by azoxystrobin. The PDI on inflorescence was also found minimum in Azoxystrobin 23\% SC @ 2ml/L followed by Azoxystrobin @ 1ml/L (Table 3). This is mainly because azoxystrobins belong to the strobilurins group, are the leading systemic fungicide, found to exert their fungicidal action by blocking electron transport in the mitochondrial respiratory chain in fungi (Gerth et al., 1980).

Significantly lower (16.64) PDI on fruits were recorded in Azoxystrobin @ 2ml/L and were maximum (50.10) in control (Table 4). There was no significant difference in Azixystrobin $23 \%$ SC and market sample of azoxystrobin
$25 \mathrm{SC} @ 1 \mathrm{ml} / \mathrm{L}$. The results on PDI on leaves, inflorescence and fruits against powdery mildew were on par in both the treatments and were the next best treatments. This might be due to the extent of inhibition of sporangial germination increased with the increase in concentration of fungicides. It was reported that among different fungicides, Azoxystrobin (23\% SC) completely inhibited the sporangial germination of powdery mildew fungus at $300 \mathrm{ppm}$ onwards (Archana, 2009).

Though standard Hexaconazole 5\% SC and Copper oxy chloride 50\% WG significantly reduced PDI on leaves, inflorescence and fruits over control, azoxystrobin was found more effective in control of powdery mildew disease in mango. Similar results were obtained by Ahiladevi et al., (2013) in grapes that Azoxystrobin 8.3\% w/w @ $0.1 \%$ inhibited conidial germination of powdery mildew fungus 'Uncinula necator' to the extent of 70.94 per cent as compared to hexaconazole $0.6 \%$ (58.73\% inhibition).

\section{Bio-efficacy of Azoxystrobin on anthracnose and yield}

The results of PDI on leaves as influenced by different fungicides against anthracnose disease are presented in Fig.1. The pooled data of two years study clearly depicts Azoxystrobin 23\% SC @ 2ml/L significantly reduced PDI on leaves (6.94) as compared to control (14.85). Azoxystrobin @ 1ml/L and standard copper oxy chloride 50\% WG @ $2.4 \mathrm{~g} / \mathrm{L}$ were the next best treatments for controlling anthracnose disease in mango. Nithyameenakshi et al., (2006) reported that in vitro study of spore germination revealed that azoxystrobin at $0.05 \%$ arrest the spore propagules of downy mildew, powdery mildew and anthracnose of grapes. 
Table.1 Phyto-toxicty observations on 0 -10 scale

\begin{tabular}{|c|c|}
\hline \multicolumn{2}{|c|}{ Scale } \\
\hline Per centage & Grade \\
\hline $0-10 \%$ & 1 \\
\hline $11-20 \%$ & 2 \\
\hline $21-30 \%$ & 3 \\
\hline $31-40 \%$ & 4 \\
\hline $41-50 \%$ & 5 \\
\hline $51-60 \%$ & 6 \\
\hline $61-70 \%$ & 7 \\
\hline $71-80 \%$ & 8 \\
\hline $81-90 \%$ & 9 \\
\hline $91-100 \%$ & 10 \\
\hline
\end{tabular}

Table.2 Per cent Disease Index (PDI) on leaves as influenced by different plant protection fungicides against Powdery Mildew Disease of Mango

\begin{tabular}{|c|c|c|c|c|c|}
\hline \multirow{2}{*}{ Sl. No } & \multirow{2}{*}{ Treatment } & \multicolumn{3}{|c|}{ PDI on Leaves } & \multirow{2}{*}{$\begin{array}{l}\text { \% Reduction } \\
\text { Over control }\end{array}$} \\
\hline & & 2012-13 & 2013-14 & Pooled & \\
\hline 1. & Azoxystrobin 23\% SC @ 1ml/L of water & $\begin{array}{c}19.28 \\
(26.04) \\
\end{array}$ & $\begin{array}{c}19.28 \\
(26.04) \\
\end{array}$ & $19.28(26.04)$ & 63.98 \\
\hline 2. & Azoxystrobin 23\% SC @ 2ml/L of water & $\begin{array}{c}18.00 \\
(25.10) \\
\end{array}$ & $\begin{array}{l}17.50 \\
(24.73) \\
\end{array}$ & $17.75(24.91)$ & 66.84 \\
\hline 3. & $\begin{array}{l}\text { Standard Azoxystrobin } 25 \mathrm{SC} @ 1 \mathrm{ml} / \mathrm{L} \text { of } \\
\text { water }\end{array}$ & $\begin{array}{c}19.70 \\
(26.35)\end{array}$ & $\begin{array}{c}19.10 \\
(25.92)\end{array}$ & $19.40(26.12)$ & 63.76 \\
\hline 4. & $\begin{array}{l}\text { Standard Hexaconazole 5\% SC @ 2ml/L } \\
\text { of water }\end{array}$ & $\begin{array}{c}24.50 \\
(29.67) \\
\end{array}$ & $\begin{array}{c}23.78 \\
(29.13) \\
\end{array}$ & $24.14(29.42)$ & 54.90 \\
\hline 5. & $\begin{array}{l}\text { Standard Copper oxy chloride } 50 \% \text { WG } \\
\text { @ } 2.4 \mathrm{~g} / \mathrm{L} \text { of water }\end{array}$ & $\begin{array}{c}27.70 \\
(33.02) \\
\end{array}$ & $\begin{array}{l}27.18 \\
(3.37) \\
\end{array}$ & $27.44(31.58)$ & 48.74 \\
\hline 6. & Control & $\begin{array}{c}54.60 \\
(47.64) \\
\end{array}$ & $\begin{array}{c}52.45 \\
(46.38) \\
\end{array}$ & $53.53(47.01)$ & \\
\hline & SEm \pm & 0.27 & 0.13 & 0.61 & \\
\hline & CD@5\% & $\mathbf{0 . 8 3}$ & $\mathbf{0 . 4 0}$ & $\mathbf{1 . 8 6}$ & \\
\hline
\end{tabular}

Figures in parenthesis indicate arcsine values.

Table.3 Per cent Disease Index (PDI) on inflorescence as influenced by different plant protection fungicides against Powdery Mildew Disease of Mango

\begin{tabular}{|c|c|c|c|c|c|}
\hline \multirow{2}{*}{ Sl. No } & \multirow{2}{*}{ Treatment } & \multicolumn{3}{|c|}{ PDI on inflorescence } & \multirow{2}{*}{$\begin{array}{l}\text { \% Reduction } \\
\text { Over control }\end{array}$} \\
\hline & & 2012-13 & 2013-14 & Pooled & \\
\hline 1. & $\begin{array}{l}\text { Azoxystrobin } 23 \% \text { SC @ 1ml/L of } \\
\text { water }\end{array}$ & $\begin{array}{c}19.50 \\
(26.21)\end{array}$ & $\begin{array}{c}18.70 \\
(25.55)\end{array}$ & $19.10(25.91)$ & 63.23 \\
\hline 2. & $\begin{array}{l}\text { Azoxystrobin 23\% SC @ 2ml/L of } \\
\text { water }\end{array}$ & $\begin{array}{c}17.50 \\
(24.73)\end{array}$ & $\begin{array}{c}16.98 \\
(34.27)\end{array}$ & $17.24(24.51)$ & 66.81 \\
\hline 3. & $\begin{array}{l}\text { Standard Azoxystrobin } 25 \text { SC @ 1ml/L } \\
\text { of water }\end{array}$ & $\begin{array}{c}19.60 \\
(26.28)\end{array}$ & $\begin{array}{c}18.63 \\
(25.55)\end{array}$ & $19.12(25.92)$ & 63.19 \\
\hline 4. & $\begin{array}{l}\text { Standard Hexaconazole 5\% SC @ } \\
2 \mathrm{ml} / \mathrm{L} \text { of water }\end{array}$ & $\begin{array}{c}24.30 \\
(29.53)\end{array}$ & $\begin{array}{c}23.45 \\
(28.93)\end{array}$ & $23.88(29.24)$ & 54.02 \\
\hline 5. & $\begin{array}{l}\text { Standard Copper oxy chloride } 50 \% \text { WG } \\
\text { @ } 2.4 \mathrm{~g} / \mathrm{L} \text { of water }\end{array}$ & $\begin{array}{c}27.90 \\
(31.88)\end{array}$ & $\begin{array}{c}26.70 \\
(31.11)\end{array}$ & $27.30(31.50)$ & 47.44 \\
\hline 6. & Control & $\begin{array}{c}52.90 \\
(46.66) \\
\end{array}$ & $\begin{array}{c}50.98 \\
(45.52) \\
\end{array}$ & $51.94(46.10)$ & \\
\hline & SEm \pm & $\mathbf{0 . 3 0}$ & $\mathbf{0 . 1 3}$ & 0.48 & \\
\hline & CD@5\% & 0.92 & 0.39 & 1.47 & \\
\hline
\end{tabular}

Figures in parenthesis indicate arcsine values. 
Table.4 Per cent Disease Index (PDI) on fruits as influenced by different plant protection fungicides against Powdery Mildew Disease of Mango

\begin{tabular}{|c|c|c|c|c|c|}
\hline \multirow{2}{*}{$\begin{array}{l}\text { Sl. } \\
\text { No }\end{array}$} & \multirow{2}{*}{ Treatment } & \multicolumn{3}{|c|}{ PDI on Fruits } & \multirow{2}{*}{$\begin{array}{l}\% \text { Reduction } \\
\text { Over control }\end{array}$} \\
\hline & & 2012-13 & 2013-14 & Pooled & \\
\hline 1. & $\begin{array}{l}\text { Azoxystrobin } 23 \% \text { SC @ } \\
1 \mathrm{ml} / \mathrm{L} \text { of water }\end{array}$ & $\begin{array}{c}18.40 \\
(25.40)\end{array}$ & $\begin{array}{c}17.70 \\
(24.88)\end{array}$ & $\begin{array}{l}18.05 \\
(25.13)\end{array}$ & 63.97 \\
\hline 2. & $\begin{array}{l}\text { Azoxystrobin } 23 \% \text { SC @ } \\
2 \mathrm{ml} / \mathrm{L} \text { of water }\end{array}$ & $\begin{array}{c}17.00 \\
(24.35)\end{array}$ & $\begin{array}{c}16.28 \\
(23.73)\end{array}$ & $\begin{array}{c}16.64 \\
(24.07)\end{array}$ & 66.79 \\
\hline 3. & $\begin{array}{l}\text { Standard Azoxystrobin } 25 \mathrm{SC} \\
\text { @ } 1 \mathrm{ml} / \mathrm{L} \text { of water }\end{array}$ & $\begin{array}{c}19.40 \\
(26.13)\end{array}$ & $\begin{array}{c}18.30 \\
(25.33)\end{array}$ & $\begin{array}{l}18.85 \\
(25.72)\end{array}$ & 62.38 \\
\hline 4. & $\begin{array}{l}\text { Standard Hexaconazole } 5 \% \\
\text { SC @ 2ml/L of water }\end{array}$ & $\begin{array}{c}23.70 \\
(29.13)\end{array}$ & $\begin{array}{c}22.63 \\
(28.38)\end{array}$ & $\begin{array}{l}23.17 \\
(28.76)\end{array}$ & 53.75 \\
\hline 5. & $\begin{array}{l}\text { Standard Copper oxy chloride } \\
50 \% \text { WG @ } 2.4 \mathrm{~g} / \mathrm{L} \text { of water }\end{array}$ & $\begin{array}{c}26.66 \\
(31.05)\end{array}$ & $\begin{array}{l}24.83 \\
(29.87)\end{array}$ & $\begin{array}{c}25.75 \\
(30.48)\end{array}$ & 48.6 \\
\hline 6. & Control & $\begin{array}{c}50.70 \\
(45.40)\end{array}$ & $\begin{array}{c}49.50 \\
(44.71)\end{array}$ & $\begin{array}{c}50.10 \\
(45.05)\end{array}$ & \\
\hline & SEm \pm & 0.33 & 0.15 & 0.51 & \\
\hline & CD@5\% & 1.01 & 0.45 & 1.53 & \\
\hline
\end{tabular}

Figures in parenthesis indicate arcsine values.

Table.5 Phyto-toxicty report of Azoxystrobin 23\% SC on mango at different intervals of Time after spraying

\begin{tabular}{|c|c|c|c|c|c|c|}
\hline \multirow{2}{*}{$\begin{array}{c}\text { Day of } \\
\text { observation } \\
\text { after each } \\
\text { spray } \\
\end{array}$} & \multirow[b]{2}{*}{ Treatments } & \multicolumn{5}{|c|}{ Phyto-toxicty Symptoms } \\
\hline & & $\begin{array}{l}\text { Leaf tips and } \\
\text { surface injury }\end{array}$ & Wilting & Vein clearing & Necrosis & $\begin{array}{l}\text { Epinasty and } \\
\text { hyponasty }\end{array}$ \\
\hline $1^{\text {st }}$ Day & $\begin{array}{ll}\text { Recommended dose }-\mathrm{X} \\
& -2 \mathrm{X} \\
& -4 \mathrm{X} \\
\text { Untreated control } & \\
\end{array}$ & $\begin{array}{l}0 \\
0 \\
0 \\
0\end{array}$ & $\begin{array}{l}0 \\
0 \\
0 \\
0\end{array}$ & $\begin{array}{l}0 \\
0 \\
0 \\
0\end{array}$ & $\begin{array}{l}0 \\
0 \\
0 \\
0\end{array}$ & $\begin{array}{l}0 \\
0 \\
0 \\
0\end{array}$ \\
\hline $3^{\text {rd }}$ Day & $\begin{array}{ll}\text { Recommended dose }-\mathrm{X} \\
& -2 \mathrm{X} \\
& -4 \mathrm{X} \\
\text { Untreated control } & \end{array}$ & $\begin{array}{l}0 \\
0 \\
0 \\
0\end{array}$ & $\begin{array}{l}0 \\
0 \\
0 \\
0\end{array}$ & $\begin{array}{l}0 \\
0 \\
0 \\
0\end{array}$ & $\begin{array}{l}0 \\
0 \\
0 \\
0\end{array}$ & $\begin{array}{l}0 \\
0 \\
0 \\
0\end{array}$ \\
\hline $5^{\text {th }}$ Day & $\begin{array}{ll}\text { Recommended dose }-\mathrm{X} \\
& -2 \mathrm{X} \\
& -4 \mathrm{X} \\
\text { Untreated control } & \end{array}$ & $\begin{array}{l}0 \\
0 \\
0 \\
0\end{array}$ & $\begin{array}{l}0 \\
0 \\
0 \\
0\end{array}$ & $\begin{array}{l}0 \\
0 \\
0 \\
0\end{array}$ & $\begin{array}{l}0 \\
0 \\
0 \\
0\end{array}$ & $\begin{array}{l}0 \\
0 \\
0 \\
0\end{array}$ \\
\hline $7^{\text {th }}$ Day & $\begin{array}{ll}\text { Recommended dose }-\mathrm{X} \\
& -2 \mathrm{X} \\
& -4 \mathrm{X} \\
\text { Untreated control } & \end{array}$ & $\begin{array}{l}0 \\
0 \\
0 \\
0\end{array}$ & $\begin{array}{l}0 \\
0 \\
0 \\
0\end{array}$ & $\begin{array}{l}0 \\
0 \\
0 \\
0\end{array}$ & $\begin{array}{l}0 \\
0 \\
0 \\
0\end{array}$ & $\begin{array}{l}0 \\
0 \\
0 \\
0\end{array}$ \\
\hline $10^{\text {th }}$ Day & $\begin{array}{ll}\text { Recommended dose }-\mathrm{X} \\
& -2 \mathrm{X} \\
& -4 \mathrm{X} \\
\text { Untreated control } & \\
\end{array}$ & $\begin{array}{l}0 \\
0 \\
0 \\
0\end{array}$ & $\begin{array}{l}0 \\
0 \\
0 \\
0\end{array}$ & $\begin{array}{l}0 \\
0 \\
0 \\
0\end{array}$ & $\begin{array}{l}0 \\
0 \\
0 \\
0\end{array}$ & $\begin{array}{l}0 \\
0 \\
0 \\
0\end{array}$ \\
\hline
\end{tabular}

Score: $0=$ No Phytotoxicity $100=100 \%$ Phytotoxicity 
Fig.1 Per cent Disease Index (PDI) on leaves as influenced by different plant protection fungicides against Anthracnose Disease of Mango

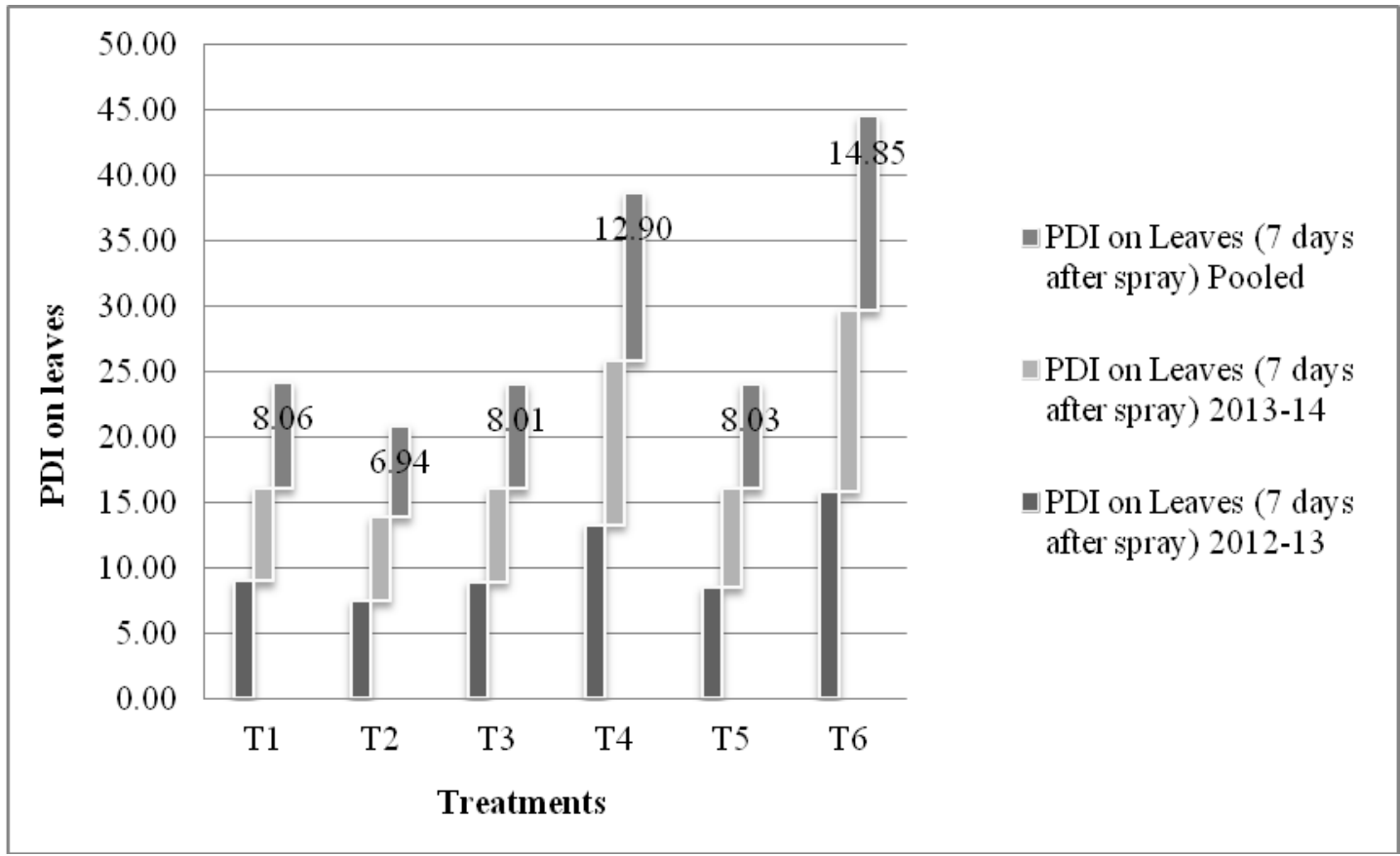

Fig.2 Effect of different plant protection fungicides on productivity of Mango

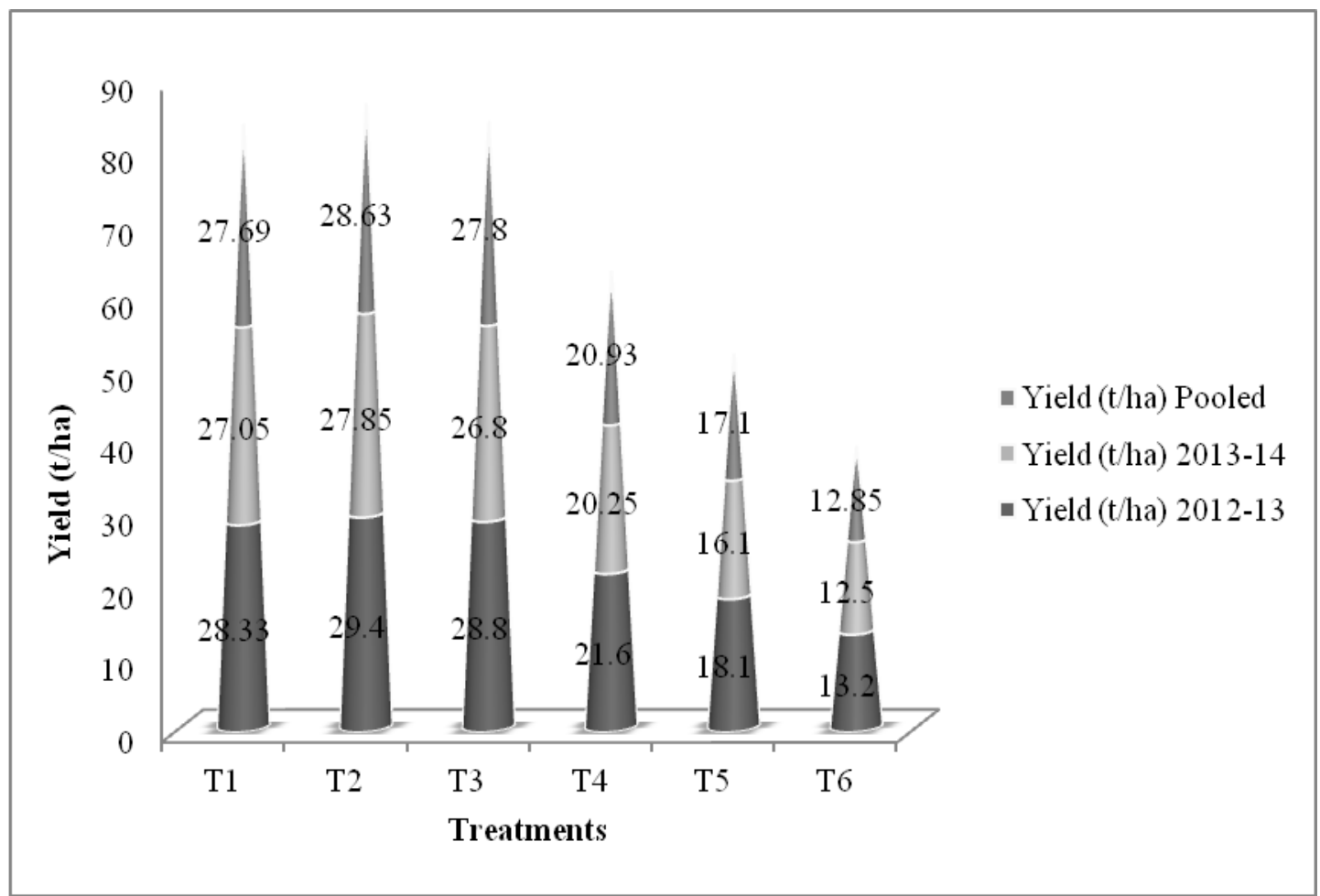

Where, $\mathrm{T}_{1}$ : Azoxystrobin 23\% SC @ 1ml/L of water; $\mathrm{T}_{2}$ : Azoxystrobin 23\% SC @ 2ml/L of water; $\mathrm{T}_{3}$ : Standard Azoxystrobin $25 \mathrm{SC} @ 1 \mathrm{ml} / \mathrm{L}$ of water; $\mathrm{T}_{4}$ : Standard Hexaconazole 5\% SC @ 2ml/L of water; $\mathrm{T}_{5}$ : Standard Copper oxy chloride 50\% WG @ 2.4g/L of water; $\mathrm{T}_{6}$ : Control 
The productivity of mango was recorded maximum (28.63 t/ha) in Azoxistrobin treatment @2ml/L followed by $1 \mathrm{ml} / \mathrm{L}$ concentration (Fig.2). The yield was significantly low in untreated control (12.85 t/ha). All fungicides significantly increased the yield as compared to untreated control. Sundravadana et al., (2007) reported azoxystrobin completely inhibited the mycelial growth of anthracnose fungi, $C$. gloeosporioides and provided more than $60 \%$ disease reduction as well as more than $40 \mathrm{~kg}$ fruits per tree in mango with no phytotoxic effect. It is also reported that blight disease of tomato and fruit rot and powdery mildew of chilli were not only effectively controlled by using Azoxystrobin 23\% SC but also enhanced yield without any phytotoxicity symptoms (Saxena et al., 2016).

Overall, Azoxystrobin 23\% SC @ 2ml/L was found to be the best treatment for controlling powdery mildew and anthracnose disease in mango. It also resulted in 122.80 per cent increase in yield over untreated control. It also revealed that the efficacy of Azoxystrobin 23\% $\quad \mathrm{SC} @ 1 \mathrm{ml} / \mathrm{L}$ against powdery mildew disease and anthracnose diseases was on par with standard Azoxystrobin 25 SC (market sample) @ $1 \mathrm{ml} / \mathrm{L}$. The results were supported by effective management of powdery mildew and anthracnose diseases of chilli by using azoxystrobin 25\% SC (Ahiladevi and Prakasam, 2013; Ahiladevi and Prakasam, 2014).

\section{Phyto-toxicty}

The result of phyto-toxicty studies of Azoxystrobin 23\% SC is presented in Table 5 . The observations on the leaf tip, surface injury, wilting, vein clearing, necrosis, epinasty, hyponasty and fruit injury were recorded during both the seasons and there were no visual symptoms of phyto-toxicty noticed on mango. Sundaravadana (2007) reported similar results that there were no phytotoxic symptoms in due to azoxystrobin application even at $4 \mathrm{ml} / \mathrm{L}$ concentration. According to the fungicide resistance action committee (FRAC, 2004) preventive use and a limited number of applications of strobilurins are recommended (i.e., no more than six per season or up to three sequential applications) to reduce the risk of phytotoxicity and development of fungicide resistance pathogen strains (Affourtit et al., 2000). Findings of our field studies suggest that azoxystrobin $23 \% \mathrm{SC}$ is effective in reducing powdery mildew and anthracnose disease on leaves, flowers and fruits at $2 \mathrm{ml} / \mathrm{L}$ concentrations. No phytotoxic symptoms were recorded after spraying on the plants even at highest dose.

It was concluded from the study that the application of Azoxystrobin 23\% SC has significantly decreased the powdery mildew and anthracnose diseases and at the same time it increased the productivity in mango. Hence, Azoxystrobin 23\% SC at the standard dose tested was found effective and comparable to the market sample and superior to other fungicides evaluated together.

\section{References}

Affourtit, C., Heaney, S. P. and Moore, A. L. 2000. Mitochondrial electron transfer in the wheat pathogenic fungus Septoria tritici: on the role of alternative respiratory enzymes in fungicide resistance. Biochimica et Biophysica Acta. 1459: 291-298.

Ahiladevi, P., and Prakasam, V. 2013. Bioefficacy of azoxystrobin $25 \%$ SC along with bio-agents against chilli anthracnose diseases under field conditions. Pest Management in Horticultural Ecosystems. 19: 57-62.

Ahiladevi, P., and Prakasam, V. 2014. Efficacy of azoxystrobin 25\% SC along with bioagents on chilli powdery 
mildew diseases under field condition. World Journal of Agricultural Science. 2 (1): 8-12.

Ahiladevi, P., Vinothini, K. and Prakasam, V. 2013. Effect of Azoxystrobin 8.3\% w/w+ Mancozeb $68.75 \%$ on powdery and downy mildew pathogens under In vitro condition. IOSR Journal of Agriculture and veterinary Science. 6 (4): 50-55.

Anand, T., Chandrasekaran, A., Kuttalam, S. P., Senthilraja, G., Raguchander, T. and Samiyappan R. 2008. Effectiveness of azoxystrobin in the control of Erysiphe cichoracearum and Pseudoperonospora cubensis on cucumber. Journal of Plant Protection Research. 48 (2): 147-159.

Archana, S., 2009. Studies on the evaluation of azoxystrobin 23 SC against Downy mildew and powdery mildew of grapevine. M.Sc. thesis. Tamil Nadu Agriculture University, Coimbatore, India.

FRAC (Fungicide Resistance Action Committee), 2004. URL http:/ /www.frac.info.

Gerth, K., Irschik, H., Reichenbach, H. and Trowitzsch, W. 1980. Myxothiazol, an antibiotic from Myxococcus fulvus (Myxobacterales) - Cultivation, isolation, physicochemical and biological properties. Journal of Antibiotics. 33:1474-1479.

Margot, P., Huggenberger, F., Amrein, J. and Weiss, B. 1998. CGA 279202: a new broad-spectrum strobilurin fungicide. In: The Proceedings of the Brighton Crop Protection Conference. Farnham,
UK: British Crop Protection Council, pp- 375-382.

Nelson, S. C., 2008a. Mango powdery mildew. Version: August 2008. URL https://www.ctahr.hawaii.edu/oc/freepu bs/pdf/PD-46.pdf

Nelson, S. C., 2008b. Mango anthracnose (Colletotrichum gloeosporioides). Version: August 2008. URL https://www.ctahr.hawaii.edu/oc/freepu bs/pdf/PD-48.pdf

Nithyameenakshi, S., Jeyaramraja, P. R. and Manian, S. 2006. Evaluation of Azoxystrobin and Difenoconazole against certain crop diseases. International Journal of Agricultural Research. 1: 420 -431.

Ploetz, R., 1999. Anthracnose: The most important disease in much of the mango producing world. The News Letter of the Plant Pathology. 3: 1-6.

Saxena, A., Sarma, B. K., Singh, H. B. 2016. Effect of Azoxystrobin based fungicides in management of chilli and tomato diseases. Proceedings of the National Academy of Sciences, India Section B: Biological Sciences. 86 (2): 283-289.

Sundravadana, S., Alice, D., Kuttalam, S., Samiyappan, R. 2007. Efficacy of azoxystrobin on Colletotrichum gloeosporiodes Penz. Growth and on controlling Mango anthracnose. Journal of Agricultural and Biological Science. 2 (3): 10-15.

Wheeler, B. E. J., 1969. An introduction to plant diseases. John Wiley and Sons Ltd., London. p.301.

\section{How to cite this article:}

Ravikumar, M.R., Vithal Navi, Yashaswini Sharma and Tippesh Chavhan. 2017. Bio- Efficacy and Phyto-Toxicty of Azoxystrobin 23\% SC against Powdery Mildew (Oidium mangiferae) and Anthracnose (Colletotrichum gloeosporioides) Diseases in Mango. Int.J.Curr.Microbiol.App.Sci. 6(10): 314-321. doi: https://doi.org/10.20546/ijcmas.2017.610.038 